\title{
The Impact of Balanced Scorecard on Improving the Performance and Profitability of the Implementing Companies
}

\author{
Arben Sahiti \\ PhD candidate, University "Kadri Zeka"Gjilan, Faculty of Economy in Gjilan, 60000 Kosovo \\ E-mail: arbens@gmail.com \\ Prof. Asoc. Dr. Skender Ahmeti \\ University of Pristina, Faculty of Economy in Pristina, 10000 Kosovo \\ E-mail: skender.ahmeti@yahoo.com

\begin{abstract}
Arbana Sahiti
PhD candidate, University of Pristina, Faculty of Economy in Pristina, 10000 Kosovo E-mail: arbana.sahiti@uni-pr.edu

University of Pristina, Faculty of Economy in Pristina, 10000 Kosovo

E-mail: muhametaliu@hotmail.com
\end{abstract} \\ Prof. Ass. Dr. Muhamet Aliu
}

Doi:10.5901/mjss.2016.v7n4p

Abstract

This research attempts to assess the impact of balanced scorecard on improving the performance and the profitability of the implementing companies. Research has been carried out using secondary data; narrative analysis has been adopted for this study. This research concludes that balanced scorecard has contributed to improve the performance and profitability for the businesses that have adopted the model.

Keywords: performance, balance scorecard, measurements, financial, business

\section{Introduction}

Long term success of a business is determined from its performance, which is directly dependent not only from the formulation and application of the correct laws, but also from the management of the sound strategies. In today's competitive business environment, companies understand that having right strategies, achieve to accomplish their business strategies, and to monitor their performance. Therefore, business aims to develop the best strategies toward performance management in order to understand how the business operates, and how it can do better.

Performance measurement is conducted from all the business in a systematic manner and sometimes ad-hoc. To assess performance of a corporation is essential its research aspect. The issue many businesses have faced is the development and application of the correct measurements that will push the strategy to improve the performance. Traditional accounting measures, which mainly focus on financial aspect have been criticized and labeled as a backward, and not relevant (Kaplan and Norton 1992). For this reason, in the contemporary time, the focus on the non-financial measurements of the performance is gaining grounds and higher support from the business community. A performance measurement tool that has gained popularity in practice and literature is balanced scorecard. This model considers necessary financial indexes, and those non-financial ones to determine the performance level of corporations. Balanced scorecard includes performance measurements from those perspectives: Financial, Customer, Internal Business Processes, Learning and Growth.

Supporters of the balanced scorecard argue that to achieve success in financial measurements, first non-financial measures have to be achieved (Davis and Albright 2004). Therefore, empirical research is necessary to determine if the focus on non-financial measures in fact leads towards better profit margins and better organizational performance using 
balanced scorecard. The aim of this research is to assess the relevance of the balanced scorecard towards the improvement of financial performance. It will show whether the focus on non-financial measures as it has been articulated from the balanced scorecard, if leads to improve financial performance.

\subsection{Rationale for research}

Balanced scorecard offers a set of balanced measurements for the management of the performance and the linkage of these measurements towards the strategic initiative for improved performance. There were some studies done in regards to the effects of the usage of balanced scorecard on the improved performance. There is an increasing trend of implementation of the balance scorecard strategy as a tool to measure the business performance (Davis and Albright 2004). It is estimated that around 44 percent of businesses in USA use balance scorecard. In general, it is perceived that balanced scorecard is mostly used in developed economies where there is high competition. As such, this research aims to assess to what extent the balanced scorecard has positively affected the performance and profitability of those businesses that implement it.

\section{Literature Review}

Balanced scorecard is used to measure performance. This is a sophisticated instrument which helps to coordinate and to arrange better operations of a company in order all of its activities to be in compliance with its strategy.

Balanced scorecard can be described as a performance management tool that eases the translation of the vision and the strategy of a company towards a tangible set of measurements. It has been suggested that a balanced set of measures should be used by businesses to enable the higher management to undertake a comprehensive view in business from four perspectives. As such, these perspectives provide answers for four substantial issues as identified below.

- Financial perspective (What we need to achieve)?

- Client perspective (How to make clients more valuable)?

- Internal business process (What we should be distinguished in)?

- Learning and growth (How we can continue to improve and create value)?

This model has been developed by Kaplan and Norton in 1992, where many mistakes have been discovered while using traditional measurement tools. In essence, balanced scorecard has been developed to improved financial methods to measure performance (Tayles et al, 2002). Kaplan and Norton (2001) argue that usage of balanced scorecard is focused on a number of management integrated ideas of accounting, which helps the manager to see the business on those four perspectives. Basically, a company that involved non-financial measures, as a part its framework, is able to track the financial results, and to monitor the required intangible aspect for higher growth. Those measures give management a balanced view of what is happening in all of its business sections, in order to help business to plan accordingly its goals and strategies on short term and long term basis.

Balanced scorecard stabilizes financial measures with non-operational measures, which are known as the key drivers of future financial performance. In this direction, balanced scorecard provides a combination of measures that will direct that which strategy will be translated towards a set of coherent of performance measures.

\subsection{Perspectives of Balanced Scorecard}

\subsubsection{Client Perspective}

This perspective takes into account the capacity of a business to secure qualitative goods and services for its clients, effectiveness of offering those services, and addresses the concerns of customers in order to develop ongoing support (Zairi dhe Jarrar, 2000). The focus here is towards the customers and how to give them value. This is because when a business loses, the drive to track and retain customers losses the credibility. And, as such no business can flourish without a customer bases which is strong. When choosing measurements for the client perspective, businesses need to provide answers on those critical questions. Who are the customers that we aim to target? What is our value proposition to serve them?

These questions present many challenges for businesses. According to Kaplan and Norton (1992), balanced scorecard requires that companies translate their mission statements in service of consumers to measure what they 
want. The inability to identify customers' needs targeted customers is one of the reasons why the strategy fails, and the perspective of balanced scorecard will be ineffective in such situation. Therefore, client perspective of the balanced scorecard, helps towards a success of a business strategy, creating values and differences from the perspective of a client. As such, customer perspective should describe the degree in which a company should fulfill its customers' needs. Objectives and measurements should be addressed in regards to the market, customer satisfaction, new purchases of customers, the issue of retaining the customers, creating long term value, and the profitability of customer segmentation (Niven, 2003).

\subsubsection{Internal Business Process Perspective}

Kaplan and Norton (1996), indicated that internal business process is critical and helps its strategic units of a business to offer clients proposals, value, and fulfill shareholders' objectives on return. Therefore, internal business process has to do with identification of critical processes, in which an organization has to thrive, in order to add values for clients, to provide competitive advantages and to achieve its objectives. This may be short and long term objective, and also the business develops innovative processes in order to generate improved performance. Internal business process of the balanced scorecard makes it distinguishable from the traditional system of performance measurement in two basic manners as it has been identified by Kaplan and Norton (1996).

First, traditional measures focus on the control and improvement of existing processes of a business. Balanced scorecard it better identifies new processes with which the business should thrive to provide customer value. Second, the traditional aspect has been focused in the creation of short term value, ignoring processes that give long term financial results. On the other hand, balanced scorecard includes new processes in the perspective of the internal business process. This is achieved identifying the customers' needs, and in this way while developing new products and services through innovation to meet customer demands

\subsubsection{Learning and growth perspective}

This perspective includes identification of the infrastructure that a business needs to develop in order to create long term and sustainable growth and ongoing improvement. It requires that management continuously improve its organizational skills to meet environment challenges faced by the competition, and to give value for its customer. Kaplan and Norton (2000) identified three sources of a business for learning and growth: people, informational system, and organizational processes. Financial perspective, client, and internal business process often identify gaps in organizational structure, through existing skills and potential abilities to achieve improved performance. These gaps can be addressed from initiatives taken from management such as investments in the training of staff, and IT (Chytas et al. 2011). Businesses may take as much as their employees, therefore, there should be real efforts to retain employees should to shoulder with knowledge and information which the perspective of learning and growth attempts to determine.

\subsubsection{Financial Perspective}

Within balanced scorecard, financial measures take a very important dimension. Financial perspective shows long term objectives of a company in order to provide value for its shareholders towards the improvement of profitability and other financial objectives. Financial measures traditionally make the basement of measurement of performance because it takes into the account the perception of shareholders in regards to financial success of a business. And seek to know if the business strategy and implementation whether are contributing towards the improvement of performance.

Kaplan and Norton (1996) identified three phases that determine one business strategy such as: fast growth, support and financial results. At the fast growth phases, businesses are in the inception phases and require more investments to develop and improve its products and services, to expand infrastructure for production, and develop relation with customers.

Business at the support phases expect to retain their market share, to gain a better return, and to continue at the expansion of its capacities. Financial objectives of the business in the phases are: return on capital, retain of market share which differs from the rapid growth phase and focuses on the increased sales in the new markets and development of new relations and existing ones. (Kaplan dhe Norton 1996). On the other hand, financial objectives at the harvest phase are related to the maximization of the monetary influxes from the existing investments. It is worth mentioning, that only financial measures are not enough to lead the performance and value creation, because they are dependent from the non-financial measures to secure results at the end lines. Key indicators of the financial performance include and are 
not limited to: growth, profit margin, and return on investments, added economic value, and market share value. Supporters of the balanced scorecard suggest that those four perspectives are inter-connected through the cause and effect relation.

\section{Methodology}

This research has been conducted using secondary data as it better fits the nature and the purpose of this research. Second hand data are the information gathered by others for the purpose that can be quite different from ours. Most of the research today requires the support of the secondary data. Using the secondary research, the author has managed to support his views with the ideas of other writers who have written about the topic.

Secondary data is also very reliable because these data have been previously collected out by various reputable organizations and world bodies. The major advantage of using secondary data is that it's faster and cheaper compared to primary data as a result resources and the time.

The data used in this research derive from a range of sources that possess high credibility, and which have been carefully reviewed and scrutinized from respective relevant bodies for quality and accuracy

The qualitative data collected has been analyzed using narrative analysis. Narrative analysis entails the analysis of a chronologically told story of events with a focus on how the elements are sequenced (Riesman 1993). Narrative analysis is seen as a more in-depth alternative to other various methods. This approach has helped to establish a form of causality particularly as regards how the balanced-scorecard has helped the companies achieve financial results.

\section{Analysis}

\subsection{Advantages and limitations of balanced scorecard}

Advantages and disadvantages of the balanced scorecard are broadly discussed in the literature from varies researchers. Balance scorecard is a very important management strategic tool, which helps business organizations not only to measure their performance, but also to define their strategies that will be used in order to improve their performance and profitability. As such, Sinha (2006) indicates that implementation of the technique can secure development of competences within organization, from where many competitive advantages will emerge to better perform as oppose to other competitors. This model attracts together, all the relevant elements of the competitive agenda of a company. However, Irala (2007) argues that the biggest obstacles towards its implementation are certain coefficients of the balanced scorecard. This view is also supported by Chytas et al. (2011), who argue that in reality all of the measures of balanced scorecard cannot have the equal coefficients as proposed by the proponents of the theory. Some of the measures may be more important than the others. They have posed the concern that while equally weighting measures among each other is important for decision making, however, some of the measures can be more important than the others.

Kaplan and Norton (1992) argue that one of the benefits of balanced scorecard is that it collects in one report many different components of competitive agenda of a company, and it leads managers' actions towards achievements of long term objectives. Another advantage of balanced scorecard is that it provides protection against under optimization, making managers to consider all of the operational measurements, while identifying the areas where improvements are achieved at the expense of the other ones (Kaplan dhe Norton 1992). It also secures information upon a continuous base as how are performing individuals, departments and other business units. This helps management to track performances and ensures quick reaction for control and evaluation. Balanced scorecard helps companies concentrate in two aspects: financial performance and non-financial performance, which are critical for the success, and for this reason it enables achievement of long term objectives within organizations (Niven 2003). Besides, balanced scorecard provides a comprehensive framework for the translation of strategic objective of an organization into a logical set of performance measurements, while developing strategic objectives for four perspectives, and then translating them into specific measurements (James, 2009). These measurements are communicated within businesses, including their strategy.

Another benefit of balanced scorecard is assumed casual relation of the four perspectives, which makes it distinct from other systems of strategic measurements (Kaplan dhe Norton 1996). Casual relationship here suggest that improvement of measurements, of learning and growth lead towards improvement of internal business processes, which should cause improvement of the client measurements, until the end that the improvement of financial measurements to be achieved. For example, balanced scorecard suggest that increase in investments for employee training will equip them with better knowledge at the operational level, which will make them create better value for customers, and as a result to 
cause improvements of financial performance of an organization (Crabtree and DeBusk 2008).

However, this assumption of causal relationship among various measurements of balanced scorecard has been criticized as being very simple. First, Norreklit (2000) provides arguments that the idea of a causal relationship can be logically defined. For example, the supporters of the theory argue that the increase of customers' loyalty should cause financial long term performance. Norreklit (2000) argue that this relationship between loyalty and customers, and the improvement of financial performance can be determined in a logical way, and not through the cause and effect relationship. Morever, Norreklit (2000) criticizes the model of balanced scorecard, while providing the arguments that there is no casual relationship between these four perspectives as they are inter-dependent on each other.

\subsection{Empirical case studies of balanced scorecard}

Hoque and James (2000) have examined the relationship and impact on businesses between improvement of organizational performance and balanced scorecard. A survey of 66 manufacturing firms has been done in Australia. Their findings suggest that bigger businesses use more the model as oppose to little ones. However, this does not suggest whether bigger businesses expect high profits from the usage of balanced scorecard. Moreover, results show a very positive relationship between measurement usage and superior performance. They have noticed that companies that are using the model have the tendency to operate in the optimal levels. Malina and Selto (2001) have examined large divisions of a big manufacturing company, with the aim to assess the efficiency of the model to communicate strategic objectives and as a tool of control for the management. Their study shows that the model has presented relevant opportunities to develop, and to communicate the business strategy. They have also found evidence between the functioning of control of balanced scorecard and the improvement performance level. Considerably, managements in their study reveal that their improved performance through the model leads to the improved efficacy of their business and profitability margins.

Other studies have examined the relationship between usage of balanced scorecard and the improved financial performance for the service industry has come up with contradicting results. Davis and Albright (2004) have studied the degree to which the use of the model improves financial performance of bank branches in the USA. Their study provides credence to propose that model can be used to improve financial performance after the findings show that branches that have used the model have exceeded those who have not on the common measurements. However, their findings greatly differ from Ittner et al (2003), who examined direct effects of using the balanced scorecard in USA from the financial service business in USA for the stock market returns. They were unable to find the important link using the model; however, they found the evidence that combination of financial and non-financial measurements is positively linked to the performance of the returns on the stock market.

Furthermore, in another broad study of financial institutions, Davis and Albright (2004) have investigated the effect of non-financial measurements on the performance of businesses. They came into conclusion, that adaption of balanced scorecard can improve performance of a company. Their findings show that businesses that have adapted the model have performed better. Similarly, these results are in line with the study done in an organization from Michalska (2005), who show that adaption of the balanced scorecard model helps to monitor the degree of implementation, and also it detects failures in the overall strategy of a business.

\section{Conclusion}

Balanced scorecard as a strategic framework of management control has generated many research, as a significant development in the management accounting. This is because of the increased popularity of the model, and it's attributed benefits. Much of the research has attempted to assess the extent to which balanced scorecard has led to improved performance and profitability of the implementing companies. Much has been written in the literature emphasizing the benefits of the model, but not many studies examine the benefits directly to financial performance related to model or to claim that the model is superior to other systems of performance measurement.

Despite opposing views of supporters and critics for the use of balance scorecard, it is important to note that model is broadly acceptable framework for the measurement of performance as it points out the two measurements of financial and non-financial performance translates a business strategy into operational terms. As a conclusion, based on the results of the empirical studies and the literature in this research, it can be said that balanced scorecard has contributed to improve the performance and profitability for the businesses that have adopted the model. 


\section{References}

Chytas, P. et al. (2011). A proactive balanced scorecard. In: International Journal of Information Management (pp. 460 - 468$)$. ISSN 0268-4012.

Crabtree, A. D., \& DeBusk, G. K. (2008). The effects of adopting the balanced scorecard on shareholder returns. Advances in Accounting Vol. 24 No1, pp 8-15.

Davis S. and Albright T. (2004), „An investigation of the effect of balanced scorecard implementation on financial performance , Management Accounting Research, Vol. 15, pp.135-153.

Hoque, Z., James, W. (2000), Linking balanced scorecard measures to size and market factors: Impact on Organizational Performance, Journal of Management Accounting Research, Vol. 12, pp. 1-17.

Irala L. R. (2007) Performance measurement using balance scorecard. [Internet] available at: http://papers.ssrn.com/sol3/papers.cfm?abstract_id=980691

Ittner, D. and Larcker.D. and. Randall. T. (2003). Performance implications of strategic performance measurement in financial services firms. Accounting, Organizations and Society 28 (2003) 715-741.

James, M. A. (2009). Measuring Performance in the Hospitality Industry: An Evaluation of the Balanced Scorecard Approach in the UK Licensed Retail Sector. Unpublished M.Phil Thesis, University of Huddersfield.

Kaplan, R. S. and D.P. Norton (1992) The Bala nced Scorecard: Measures that Drive Performance, Harvard Business Review,(JanuaryFebruary): 71-79.

Kaplan, R. S. and Norton, D. P. (1996) "The Balanced Scorecard: Translating Strategy into Action". Harvard Business School Press, Cambridge, MA.

Kaplan, R. S. and Norton, D. P. (2001) "Transforming the Balanced Scorecard from Performance Measurement to Strategic Management: Part I", American Accounting Association, Vol. 15, No. 1, pp. 87-104

Malina, M.A., Selto, F.H., (2001). Communicating and controlling strategy: an empirical study of the effectiveness of the Balanced Scorecard. Journal of Management Accounting Research, Vol. 13, pp 47-90.

Michalska, J. (2005). The usage of the Balanced Scorecard for the estimation of the enterprises effectiveness. Journals of Materials Processing Technology, vol. 16, no.2, pp. 751-758.

Niven, P. R. (2003). Balanced scorecard: Step-by-step for government and non-profit agencies. Hoboken, NJ: John Wiley \& Sons, Inc.

Norreklit, H. (2000) The balance on the balanced scorecard: A critical analysis of some of its assumptions, Management Accounting Research, 11, 1, pp.65-88.

Rigby, D. (2001). Management Tools and Techniques: A Survey. California Management Review, 43(2), 139-160.

Riesman, C. K. (1993) Narrative analysis, CA: Sage Publications.

Sinha, A (2006), Balanced Scorecard: A Strategic Management Tool, Vidyasagar Univeristy Journal of Commerce, Vol. 11.

Tayles, M., Bramley, A., Adshead, N and Farr, J. (2002). Dealing with the Management of Intellectual Capital: The potential role of Strategic Management Accounting. Accounting, Auditing and Accountability Journal, vol.15, no.2, pp. 251-267.

Zairi, M. and Jarrar. Y.F. (2000), Internal transfer of best practice for performance excellence: a global survey, Benchmarking: An International Journal, Vol.7, No.4, pp 239-246. 